\title{
An Investigation into Secondary School Students' Sino-Vietnamese Competence in Philology Learning Activities
}

\author{
Lan Thi Trinh ${ }^{1+}$, \\ Tu Cam Thi Nguyen', \\ Anh Ngoc Thi Nguyen ${ }^{3}$
}

\section{Article history}

Received: 10 March 2021

Accepted: 18 June 2021

Published: 30 June 2021

\section{Keywords \\ Vocabulary capacity, Sino- \\ Vietnamese, Philology, 2018 \\ General Education \\ Curriculum}

\author{
${ }^{1}$ Hanoi National University of Education, Vietnam; \\ ${ }^{2}$ Nguyen Tat Thanh Secondary and High School - Hanoi National University \\ of Education, Vietnam; ${ }^{3}$ Xuan Phuong High School, Hanoi, Vietnam \\ ${ }^{+}$Corresponding author $\bullet$ Email: lantrinh@hnue.edu.vn
}

\section{INTRODUCTION}

Sino-Vietnamese vocabulary is an important part of the Vietnamese language system. This is not only illustrated in Vietnamese dictionaries but also can be observed in the practical usage of the language in all fields by Vietnamese people. In the Literature curriculum and textbooks from elementary school to high school, teaching the contents of Sino-Vietnamese vocabulary is always prioritised as a significant proportion in the students' key Vietnamese knowledge and skills. In secondary schools, in addition to being designed as a specific unit of knowledge in a lesson, or a Vietnamese lesson in the Literature curriculum, Sino-Vietnamese vocabulary is also a part of the outcome requirements for some integrated reading and writing lessons in the textbooks for Grade 6 to 9 (as of the 2006 Literature curriculum), is included with high frequency in teaching materials for reading and writing, closely integrated with the notes for attention in these materials and in accordance with the expected quantity of SinoVietnamese elements in students' Vietnamese vocabulary at different levels. In both the curriculum and the Literature teaching practice in secondary schools, it is crucial to conduct studies to evaluate students' ability to use SinoVietnamese vocabulary and, thereby propose effective teaching solutions to promote students' Sino-Vietnamese vocabulary capacities, as well as to improve the effectiveness of teaching Vietnamese language in school.

\section{LITERATURE REVIEW}

\section{1. "Language competence" and "verbal competence"}

Chomsky (1965) first coined the term "linguistic competence" as the knowledge of the speaker-listener about their own language, as opposed to "language practice", which is understood as the practical usage of the language in specific situations. The linguistic knowledge system, or "language code" includes the following areas:

- Grammar: Morpheme and syntax (word order).

- Phonemes: Vowels, consonants, word stress, sentence stress, intonation, etc.

- Vocabulary: Words and word combinations. 
- Mechanics: Spelling and punctuation

In this system, vocabulary is one of the language "codes" and 'verbal competence' is one of the constituent parts of language competence.

Nation (1990) later got deeper into the realm of "verbal competence" by providing an explanatory table about "how to know what a word means", both in terms of receptive and textual creation knowledge. This table includes questions that a person who "knows" a word can answer:

Table 1. A table of questions for people who "know what a word means" (Nation, 1990)

\begin{tabular}{llll}
\hline \multirow{2}{*}{ Form } & \multicolumn{2}{c}{ Perceive } & \multicolumn{2}{c}{ Produce } \\
\cline { 2 - 4 } & Speech & How does the word sound? & How do you pronounce the word? \\
\cline { 2 - 4 } Position & Written & How does the word look? & How do you write and spell the word? \\
\cline { 2 - 4 } & $\begin{array}{l}\text { Grammar } \\
\text { structure }\end{array}$ & $\begin{array}{l}\text { This word appears often in what } \\
\text { type of sentence? }\end{array}$ & $\begin{array}{l}\text { In what sentence structure should we } \\
\text { use this word in? }\end{array}$ \\
\cline { 2 - 5 } Function & $\begin{array}{l}\text { Word } \\
\text { positioning }\end{array}$ & $\begin{array}{l}\text { Which word or word form can } \\
\text { stand before/ after this word? }\end{array}$ & $\begin{array}{l}\text { Which word/ word form should be } \\
\text { used with this word? }\end{array}$ \\
\cline { 2 - 4 } Meaning & Frequency & How common is this word? & How often can we use the word? \\
\cline { 2 - 4 } & Conformity & Where can we find this word? & Where can we use the word? \\
\cline { 2 - 4 } & Term & What does this word mean? & $\begin{array}{l}\text { What word should be used to explain } \\
\text { this meaning? }\end{array}$ \\
\cline { 2 - 4 } & Relationship & $\begin{array}{l}\text { What other words can we think of } \\
\text { when we see this word? }\end{array}$ & $\begin{array}{l}\text { What alternatives can we use other } \\
\text { than this word? }\end{array}$ \\
\hline
\end{tabular}

In the process of teaching and learning a language, the provision and practice of words play a crucial role. It is usually conducted at the very first lesson and is almost decisive for the learner's understanding and communication process. Perhaps therefore Swan and Walte, in "A course of English" (1948), affirmed that: "Acquiring words is the most important and greatest task for a language learner..." (cited by Nguyen, 2010).

Some studies by other authors like Gairns \& Redman (1986), Carter \& McCarthy (1988) also agree that verbal competence is considered a component of language competence, and at the same time these authors agree with the point of view of educators who consider verbal competence as an instrumental ability because it plays an important role in providing means for learners to acquire these competencies effectively.

In Vietnam, in a guide to teaching Literature, Do (2018) presented a view that: "Language competence is the ability to use speech and text in communication, expressed in reading, writing, speaking and listening skills". In some other studies, it is also suggested that it is necessary to add viewing and presentation skills to language competence, and, at the same time, separate language competence into two types: receptive ability (reading, listening, seeing) and productive ability (writing, speaking, presenting).

We also stand at this research angle, considering verbal competence as a part of language competence, in terms of language unit level, agreeing with the view that verbal competence includes the following elements:

- Vocabulary and knowledge of words in vocabulary: expressed in the quantity of vocabulary; knowledge of words (phonetics, semantics, grammar).

- Skills of using words to receive and produce texts: including skills of using words in listening and reading activities (perceiving texts); skills in using words in speaking and writing activities (text production) to suit narrow (textual) and broad (intertextual) contexts.

- Personal psychological and emotional attributes such as motivation, belief, will, emotion, etc. that are related to words are also considered in the process of users applying them to the process of listening and speaking, as well as reading and writing, not only in learning but also in communication practice.

\subsection{Sino-Vietnamese}

In Vietnamese language, Sino-Vietnamese vocabulary holds an important position as an indispensable part of the spoken and written language of Vietnamese people. Previous research on Vietnamese vocabulary system and practical Vietnamese language all mentions the topic of Sino-Vietnamese. Nguyen (1985) and many other researchers asserted that Sino-Vietnamese vocabulary belongs to one of the Vietnamese lexical classes without any semantic relationship. These lexical classes are classified as pairs, namely: Vietnamese native words and borrowed words, standard language and dialect, old words and new words, etc. Sino-Vietnamese vocabulary composes a major group of words, belonging to the class of borrowed words and accounting for a large proportion in Vietnamese 
language. This classification of Sino-Vietnamese aims to distinguish itself from borrowed words from other languages. Sino-Vietnamese vocabulary includes Vietnamese words with elements borrowed from the Chinese language. These words have been Vietnamese-ized in pronunciation to match the phonetic system of Vietnamese. In Vietnamese, Sino-Vietnamese vocabulary possesses a very high frequency of occurrence, especially in written documents, and is popular in all fields of social life. A number of studies in the field of linguistics have shown that in daily communication of Vietnamese people, there is a great need for Sino-Vietnamese vocabulary, especially during events, or in programs, scripts, serious and formal text, where this need is heightened. Sino-Vietnamese vocabulary is not only present in literature and art, but also in all types of text in different fields. Specific studies on Sino-Vietnamese elements, structures, and interpretations are also quite common, but there are very few research works on teaching Sino-Vietnamese vocabulary to different learners, including students at all levels of education. Recently, the research of Nguyen (2015a, 2015b, 2019) delved into the nature of Sino-Vietnamese vocabulary, and at the same time associating the storage and development of Sino-Vietnamese word sources with the use of SinoVietnamese vocabulary at school and in social communication settings.

Through the investigation into Literature textbooks in secondary schools (for the 2006 general education program), it is found that at the end of the Literature textbook's second volumes for all four grades from 6 to 9 , there is an Appendix to look up Sino-Vietnamese factors with 220 words (in which grade 6, 7, 8 has 50 words each, and grade 9 has 70 words).

In the Literature General Education Program (Issued together with Circular No. 32/2018/TT-BGDDT, dated December $26^{\text {th }}, 2018$, by the Minister of Education and Training), the Sino-Vietnamese teaching content is shown specifically and clearly in the program from grade 4 to grade 9 . The teaching content is shown through the outcome statements, as for the secondary school level including: Students can understand the meanings of some common Sino-Vietnamese elements and the meanings of those Sino-Vietnamese vocabulary (grades 6, 7, 8); Students can recognize the difference in meaning of some confusing Sino-Vietnamese elements (grade 9).

From the concept of vocabulary competence above, in this study, Sino-Vietnamese comprehension ability would include the following elements:

(1) Sino-Vietnamese vocabulary: including the recognization and interpretation of Sino-Vietnamese vocabulary, as well as Sino-Vietnamese word origins.

(2) Ability to enrich Sino-Vietnamese vocabulary: demonstrated by recognizing, making academic prediction and determining the correct or relatively correct meaning of Sino-Vietnamese vocabulary based on the original SinoVietnamese meaning.

(3) Ability to use Sino-Vietnamese vocabulary: not only by determining the correct meaning of words but also by applying Sino-Vietnamese vocabulary into specific communication situations, or in learning activities such as reading, listening and speaking, writing (text production).

To develop language competence for secondary students, it is necessary to pay attention to and have effective solutions to developing the ability to use Sino-Vietnamese vocabulary in particular. Good Sino-Vietnamese vocabulary would partially facilitate students' reading, writing, speaking and listening processes more smoothly and effectively.

\section{MATERIALS AND METHODS}

Our research mission is to examine the reality to evaluate the situation, initially assess the actual Sino-Vietnamese capacity of secondary students and propose a number of Sino-Vietnamese capacity enhancing solutions for middle school students. Specifically, the research methods include:

- Documents analysis: This method is used to study the concepts of tools and scientific knowledge related to Sino-Vietnamese vocabulary and the use of Sino-Vietnamese vocabulary of students, including the following steps: analysis, synthesis, systemization of documents on Sino-Vietnamese vocabulary, language capacity, word ability, teaching capacity development in Vietnam and around the world.

- Empirical research methods: The methods are employed to assess the current use of Sino-Vietnamese vocabulary of secondary schoolers, mainly grade 6 through observation; questionnaires for students, class worksheets to evaluate students' Sino-Vietnamese competence...

- Statistics and data processing: after collecting student questionnaires and worksheets, this step was conducted to assess students' Sino-Vietnamese capacity. 
The research subjects are $2126^{\text {th }}$ graders of two secondary schools in Hanoi, Nguyen Tat Thanh Secondary and High School and Me Tri Secondary School. This subject is randomly selected and evaluated in terms of the ratio of gender and language level.

The data was collected through a questionnaire designed with Google Forms. The questionnaire aims to find out the situation of access and application of Sino-Vietnamese vocabulary using a five-point scale including: Very often - Often - Sometimes - Rarely (Hardly ever) - Never. The items include the following contents: Do you encounter and have to explain Sino-Vietnamese words in the process of reading and understanding the text? Do you use the SinoVietnamese vocabulary for writing sentences and passages in class? Do you use Sino-Vietnamese vocabulary in speaking and listening in class? How do you use Sino-Vietnamese vocabulary for everyday communication? Does your teacher support you in learning the meaning and use of the Sino-Vietnamese vocabulary for learning? Do you think it is necessary to study Sino-Vietnamese vocabulary in secondary school today? Do you think studying SinoVietnamese words in secondary school now suits your level and needs? What do you propose to make your students' learning and use of Sino-Vietnamese vocabulary more effective? The questionnaire is designed with Google Forms to collect the results more quickly, conveniently, and clearly regarding respondents' personal information, as well as ensure the confidentiality of private information in the survey. The survey result is a specific score of each individual in relation with the score and the time of submission.

Researchers also aim to assess the actual Sino-Vietnamese capacity of students through a test. The test is designed as an in-class worksheet, including both objective multiple choice questions and short answer ones. Specifically, the following types of exercises are included: Selecting the Sino-Vietnamese vocabulary that corresponds to the given image, identifying the meaning of the language items(or of the italic words) in the Sino-Vietnamese vocabulary, Finding more Sino-Vietnamese words containing the Chinese-root element with the similar meaning (find at least 3 more Sino-Vietnamese vocabulary with each Element of the given Chinese-root element), Identifying the mistake and correct Sino-Vietnamese vocabulary, Selecting the correct answer in the given words, Completing the sentences/ texts, Writing sentences with the given Sino-Vietnamese vocabulary.

Based on the requirements of the exercises and the score obtained from the worksheets, the authors have designed the table for the assessment of Sino-Vietnamese competence of secondary schoolers, mainly grade 6 students using the rubrics as follows:

Table 2. Rubrics to assess Sino-Vietnamese competence of grade 6 students

\begin{tabular}{|c|c|c|c|c|}
\hline Criteria & $\begin{array}{c}3 \\
\text { (Competent) }\end{array}$ & $\begin{array}{c}2 \\
\text { (Satisfactory) }\end{array}$ & $\begin{array}{c}1 \\
\text { (Requires } \\
\text { additional support) }\end{array}$ & $\begin{array}{c}\mathbf{0} \\
\text { (Incompetent) }\end{array}$ \\
\hline $\begin{array}{l}\text { 1. Sino- } \\
\text { Vietnamese } \\
\text { Vocabulary } \\
\text { Range }\end{array}$ & $\begin{array}{l}\text { Abundant } \\
\text { vocabulary, } \\
\text { expanding beyond } \\
\text { the scope learned in } \\
\text { many different fields. } \\
\text { Find } 15-20 \text { words } \\
\text { with given root } \\
\text { meanings. } \\
\text { (16-20 points) }\end{array}$ & $\begin{array}{l}\text { Sufficient vocabulary } \\
\text { to express basic, } \\
\text { daily communication } \\
\text { needs, including } \\
\text { learned words. Find } \\
\text { 9-14 words with root } \\
\text { meanings given. } \\
\text { (11-15 points) }\end{array}$ & $\begin{array}{l}\text { Only basic } \\
\text { vocabulary related to } \\
\text { familiar everyday } \\
\text { situations. Find less } \\
\text { than } 9 \text { words with the } \\
\text { given root meanings. } \\
\text { (6-10 points) }\end{array}$ & $\begin{array}{l}\text { No words presented } \\
\text { or identify words that } \\
\text { are not correct } \\
\text { regarding the given } \\
\text { root meaning. } \\
\text { (0-5 points) }\end{array}$ \\
\hline $\begin{array}{l}2 . \\
\text { Recognizing } \\
\text { Sino- } \\
\text { Vietnamese } \\
\text { vocabulary }\end{array}$ & $\begin{array}{l}\text { Delicately recognize } \\
\text { Sino-Vietnamese } \\
\text { vocabulary, Chinese- } \\
\text { roots, deeply } \\
\text { understand the } \\
\text { meanings of words, } \\
\text { including hidden } \\
\text { meanings. }\end{array}$ & $\begin{array}{l}\text { Accurately } \\
\text { identifying Sino- } \\
\text { Vietnamese } \\
\text { vocabulary, Chinese- } \\
\text { roots, correctly } \\
\text { understanding the } \\
\text { main meanings of the } \\
\text { word, which } \\
\text { summarise the } \\
\text { concept that the word } \\
\text { expresses. }\end{array}$ & $\begin{array}{l}\text { Identifying Sino- } \\
\text { Vietnamese } \\
\text { vocabulary, but still } \\
\text { misunderstanding the } \\
\text { Chinese-roots, } \\
\text { understanding the } \\
\text { meanings of words in } \\
\text { a basic way, having } \\
\text { difficulty in } \\
\text { expressing the } \\
\text { concept that words } \\
\text { refer to. }\end{array}$ & $\begin{array}{l}\text { Unable to recognize } \\
\text { Sino-Vietnamese } \\
\text { vocabulary, Chinese- } \\
\text { roots, misunderstand } \\
\text { the meanings of the } \\
\text { word, unable to point } \\
\text { out the concept that } \\
\text { the word refers to. }\end{array}$ \\
\hline
\end{tabular}




\begin{tabular}{|c|c|c|c|c|}
\hline $\begin{array}{l}\text { 3. Sino- } \\
\text { Vietnamese } \\
\text { Vocabulary } \\
\text { expansion }\end{array}$ & $\begin{array}{l}\text { Having the ability to } \\
\text { relate quickly and } \\
\text { flexibly mobilize } \\
\text { existing background } \\
\text { Sino-Vietnamese } \\
\text { vocabulary to create } \\
\text { Sino-Vietnamese } \\
\text { words from the } \\
\text { known root } \\
\text { meanings. }\end{array}$ & $\begin{array}{l}\text { Able to relate to } \\
\text { existing background } \\
\text { Sino-Vietnamese } \\
\text { words with support } \\
\text { to create Sino- } \\
\text { Vietnamese } \\
\text { vocabulary from the } \\
\text { root meaning but } \\
\text { there are some } \\
\text { mistakes. }\end{array}$ & $\begin{array}{l}\text { The ability to relate } \\
\text { is weak and limited, } \\
\text { repeating only } \\
\text { known words; the } \\
\text { creation of Sino- } \\
\text { Vietnamese } \\
\text { vocabulary is limited } \\
\text { to simple, familiar } \\
\text { roots. }\end{array}$ & $\begin{array}{l}\text { Unable to relate to } \\
\text { and mobilize existing } \\
\text { words in memory, } \\
\text { the ability to create } \\
\text { Sino-Vietnamese } \\
\text { vocabulary from the } \\
\text { root meaning is very } \\
\text { poor. }\end{array}$ \\
\hline $\begin{array}{l}4 . \\
\text { Understanding } \\
\text { Sino- } \\
\text { Vietnamese } \\
\text { vocabulary in } \\
\text { receptive } \\
\text { activities }\end{array}$ & $\begin{array}{l}\text { Can recognise, } \\
\text { understand and } \\
\text { explain in detail } \\
\text { almost all the Sino- } \\
\text { Vietnamese } \\
\text { vocabulary in the } \\
\text { text. Use Sino- } \\
\text { Vietnamese } \\
\text { deliberately in } \\
\text { specific cases of } \\
\text { communication } \\
\text { according to the } \\
\text { context, object, level } \\
\text { of formality. }\end{array}$ & $\begin{array}{l}\text { Can recognise, } \\
\text { understand and } \\
\text { explain many Sino- } \\
\text { Vietnamese } \\
\text { vocabulary in the } \\
\text { text. Accurately use } \\
\text { Sino-Vietnamese in } \\
\text { specific cases of } \\
\text { communication } \\
\text { according to context, } \\
\text { object, level of } \\
\text { formality. }\end{array}$ & $\begin{array}{l}\text { Can recognize and } \\
\text { understand at a basic } \\
\text { level familiar Sino- } \\
\text { Vietnamese } \\
\text { vocabulary, with the } \\
\text { highest frequency of } \\
\text { appearance in the } \\
\text { types of texts. Use } \\
\text { Sino-Vietnamese } \\
\text { with confusion in } \\
\text { specific cases of } \\
\text { communication } \\
\text { according to context, } \\
\text { object, level of } \\
\text { formality. }\end{array}$ & $\begin{array}{l}\text { Unable to recognize } \\
\text { and understand the } \\
\text { Sino-Vietnamese } \\
\text { vocabulary in the } \\
\text { texts. Misuse, do not } \\
\text { know how to use the } \\
\text { Sino-Vietnamese in } \\
\text { specific cases of } \\
\text { communication } \\
\text { according to the } \\
\text { context, object, level } \\
\text { of formality. }\end{array}$ \\
\hline $\begin{array}{l}5 . \text { Use of } \\
\text { Sino- } \\
\text { Vietnamese } \\
\text { vocabulary in } \\
\text { productive } \\
\text { activities }\end{array}$ & $\begin{array}{l}\text { Able to use Sino- } \\
\text { Vietnamese } \\
\text { vocabulary in a rich, } \\
\text { accurate and } \\
\text { appropriate way to } \\
\text { produce texts with } \\
\text { good grammar } \\
\text { structures, attractive } \\
\text { and inspiring } \\
\text { contents. }\end{array}$ & $\begin{array}{l}\text { Able to use Sino- } \\
\text { Vietnamese } \\
\text { vocabulary correctly } \\
\text { in producing texts } \\
\text { with the appropriate } \\
\text { grammar structures, } \\
\text { logical contents, but } \\
\text { still with confusion. }\end{array}$ & $\begin{array}{l}\text { Able to use very } \\
\text { basic Sino- } \\
\text { Vietnamese } \\
\text { vocabulary in the } \\
\text { production of texts, } \\
\text { with confusing } \\
\text { grammar structures, } \\
\text { illogical contents. }\end{array}$ & $\begin{array}{l}\text { The ability to use the } \\
\text { Sino-Vietnamese } \\
\text { vocabulary is very } \\
\text { low; unable to } \\
\text { compose complete } \\
\text { sentences, incorrect } \\
\text { grammar and } \\
\text { content. }\end{array}$ \\
\hline
\end{tabular}

In addition to this criterion evaluation, the researchers also refer to the students' practical activities through the collection and evaluation of daily exercises, ongoing and end-of-term tests of the participants to withdraw more comprehensive comments.

\section{RESULTS AND DISCUSSION}

The results of our research are shown in the presentation of the aforementioned process, survey methods and assessment tools. In addition, we also have the results obtained after processing the students' questionnaires and tests on Sino-Vietnamese. The specific details are presented below:

\subsection{Results on the practical usage of Sino-Vietnamese vocabulary in classroom learning activities for secondary school students}

The findings from the Google Forms questionnaires (by asking subjective questions with 212 6th grade students in two secondary schools in Hanoi) are as follows: $47.8 \%$ and $32.8 \%$ of students confirmed that they were occasionally and often exposed to texts containing Sino-Vietnamese vocabulary respectively while less than $1 \%$ said they had never been exposed to these types of text. This shows that the Literature curriculum and textbooks have paid adequate attention to the goal of allowing students to get regular and continuous access to Sino-Vietnamese vocabulary from different sources, especially focusing on reading and writing materials. Regarding the application of knowledge of Sino-Vietnamese vocabulary into skill-based activities such as reading, writing, speaking and listening, $7.5 \%$ of students regularly produced sentences and texts containing Sino-Vietnamese vocabulary; $37.3 \%$ 
and $31.3 \%$ are the percentages of students who used these words frequently and occasionally, respectively. In the process of practicing speaking and listening in class, more than $35 \%$ of the surveyed students regularly used SinoVietnamese vocabulary in their expressions, and only $6 \%$ thought that they never used them. When asked about the necessity of learning Sino-Vietnamese vocabulary in the secondary school curriculum, $88 \%$ of the students who participated in the survey expressed that this was necessary while only $12 \%$ of the students said that it was not very important. This result is obtained from the subjective opinions of $6^{\text {th }}$ graders, which is used as a main basis for proposing solutions to affect the learners' attitudes.

\subsection{Results on the ability to use Sino-Vietnamese vocabulary through worksheets}

The results indicate that $5 \%$ of the students achieved a score within the range of 90-100 points on the worksheet; $40 \%$ score in the range of $80-90 ; 50 \%$ were in the 65-80 range and the rest was below average. This result partly demonstrates students' ability to understand the structure of Sino-Vietnamese vocabulary as well as the root meanings of Sino-Vietnamese vocabulary (Sino-Vietnamese elements) is only slight beyond average; the cases in which students do not understand, misunderstand, or confuse between Sino-Vietnamese elements in SinoVietnamese vocabulary, leading to misunderstanding of Sino-Vietnamese vocabulary, are also quite common. Particularly, many students still make mistakes or have misunderstandings while doing basic recognition exercises, such as determining the meaning of Sino-Vietnamese vocabulary or interpreting Sino-Vietnamese vocabulary based on their structures; proposed Sino-Vietnamese words are not very rich; and there are still the cases of students using the wrong context or inappropriate word in a sentence, etc. It is revealed that the knowledge of Grade 6 students about Sino-Vietnamese vocabulary, as well as the ability to apply Sino-Vietnamese vocabulary in reading and writing activities in Literature lessons, is not good. There should be a more appropriate and effective consideration to help enhance these students' ability to use Sino-Vietnamese during in-class Literature learning activities.

Through a self-assessment questionnaires and tests to evaluate the ability to use Sino-Vietnamese vocabulary among grade 6 students, with the addition of observing the students' learning behavior towards Sino-Vietnamese vocabulary during Literature lessons, it is found out that students are not really interested in learning SinoVietnamese, and the ability to understand and use Sino-Vietnamese vocabulary varies greatly among these students, while still being very limited. Students have little exposure to rich and methodical Sino-Vietnamese vocabulary sources, and at the same time, students rarely practice and apply them regularly in learning activities in the classroom; this results in the lack of effectiveness, vocabulary limitation, confusion and misuse of Sino-Vietnamese vocabulary being pretty common for grade 6 students.

Combining this practical situation with the theoretical background on Sino-Vietnamese language regarding language education and vocabulary development for secondary school students, we have proposed a number of measures to develop Sino-Vietnamese vocabulary for secondary school students as follows:

First of all, it is necessary to have a system of exercises to develop the Sino-Vietnamese competence fully, richly and realistically to language perception of secondary school students. The system of exercises is firstly used during Literature in-class activities, and also serves as a tool to help students self-study and self-practice Sino-Vietnamese. These types of exercises should cover all levels of awareness: they need to recognize, understand, apply and develop language capacity: expanding, systematizing, and making Sino-Vietnamese more active. The texts used in the exercise need to contain Sino-Vietnamese roots that students have already known, used, or consists of specific contexts so that the use of words becomes more convenient.

The next thing is that secondary schools should encourage students to use specialized Sino-Vietnamese dictionaries for students of all grades that are simple, well-designed and user-friendly, accompanied by examples, and can be divided according to topics familiar with students through documents in the curriculum or in real life, so that learners can easily access and look up, as well as apply them in communication scenarios and during learning activities in the classroom.

Lastly, in order to meet and take advantage of the requirements of mechanized and digitized education in general, it is vital to bring information technology applications into teaching Sino-Vietnamese vocabulary in schools: websites, softwares, Sino-Vietnamese vocabulary lookup programs, language games on digital devices will aid teachers in delivering their lessons and help the students' process of learning Sino-Vietnamese vocabulary become more attractive and exciting.

Because secondary school students have specific cognitive abilities in general and language proficiency in particular, we only propose familiar, easy to implement, and highly feasible solutions. These proposals will open up new research on teaching methods for Sino-Vietnamese vocabulary in the direction of learners' competence 
development, as well as supporting tools for learning Sino-Vietnamese vocabulary that can fit different Vietnamese learners.

The results of the study may be limited due to the scope of the study which only focuses on grade 6 students. The responses obtained from the respondents (grade 6 students) are subjective; however, the reference value of these results are still very clear and worth noting. The solutions to develop the Sino-Vietnamese vocabulary with more details would be presented in the upcoming scientific works.

\section{CONCLUSION}

The Sino-Vietnamese vocabulary capacity reflects the language competence of secondary school students in classroom activities. Developing language competence for learners at this level is the goal and essential content of the 2018 general education curriculum for Literature, as well as a compulsory language education task of schools. However, the specific impacts to develop this component competence of language competence have not been really interested in and focused on. Our study focuses on investigating the current situation of Sino-Vietnamese vocabulary learning of middle school students, a group of teenagers which is developing and perfecting the language capacity in many aspects. This survey was conducted in the context that secondary schools in Vietnam still use teaching materials following the 2006 General Education Curriculum, but according to the orientation of the 2018 General Education Curriculum. It is advantageous that both programs aim to build vocabulary and the ability to apply Sino-Vietnamese vocabulary into learning activities and social activities in general. Although the content of this study is not new, it is always a valuable reference for adjusting teaching practice, setting itself as a premise to propose solutions for teaching Sino-Vietnamese vocabulary in secondary schools, and at the same time open up new research directions for those interested in language development and language education in educational institutions.

Acknowledgements: This research is funded by Vietnam National Foundation for Science and Technology Development (NAFOSTED) under grant number 602.02-2019.02.

\section{REFERENCES}

Carter, R. \& McCarthy, M. (1988). Vocabulary and Language Teaching. London: Longman.

Chomsky, N. (1965). Aspects of the Theory of Syntax. Cambridge Mass, MIT Press.

Do, N. T. (2018). Teaching Philology to develop learners' competences in secondary school. University of Education Publishers.

Gairns, R. \& Redman, S. (1986). Working with Words. Cambridge, Cambridge University Press.

Larsen-Freeman, D. (2000). Techniques and principles in language teaching. Oxford University Press.

Ministry of Education and Training, Vietnam (2006). Literature General Education Curriculum (Issued under Decision No. 16/2006/QD-BGDDT dated May 5, 2006).

Ministry of Education and Training, Vietnam (2018). General Education Curriculum in Literature (Issued under Decision No. 32/2018/TT-BGDDT dated December 26, 2018).

Nation, I. S. P. (1990). Teaching and learning vocabulary. New York, Newbury House.

Nguyen, C. H. (2010). Teaching Content and methodology of Vietnamese vocabulary. Vietnam National University Press, 31, 44.

Nguyen, Q. (2016). From language competence to intercultural competence. VNU Journal of Science: Foreign research, 32(3), 1-9.

Nguyen, T. G. (1985). Vietnamese vocabulary. University and Professional High School Publishers.

Nguyen, T. T. C. (2015a). From tracing Chinese synonyms to tracking the root of Sino-Vietnamese vocabulary. Do Нии Chau - Journey and Succession. Vietnam National University, 206-214.

Nguyen, T. T. C. (2015b). Teaching Sino-Vietnamese by Chinese Interpreting Method. Innovation in Research and Teaching Literature in Pedagogical School, Vietnam Education Publishing House, 342-349.

Nguyen, T. T. C. (2019). An explanation of Chinese in Tang poetry and Vietnamese medieval poetry. Hanoi University of Education Publishers.

Nunan, D. (1991). Language teaching methodology. National Center for English Language Teaching and Research, Macquarie University, Sydney. 